\title{
The impact of social media on young web users' psychological well-being during the COVID-19 pandemic progression
}

\section{Вплив соціальних мереж на психологічне благополуччя юних web-користувачів в період прогресування пандемії COVID-19}

Received: March 27, 2021

\section{Abstract}

Aim. The present study empirically investigates and theoretically substantiates the results of the impact of social media on young web-users' psychological well-being during the forced selfisolation caused by the progression of the COVID-19 pandemic $(\mathrm{N}=254)$. Materials and methods. Standardized valid psycho-diagnostic methods, the author's questionnaire (A. Hudimova, 2021), correlation and factor analyses were used to identify young web users' patterns of social media involvement during the forced self-isolation. Results. The results show that during the global COVID-19 pandemic, young web users give preference for passive social media use rather than for communication. The obtained results showed an expansion in the time spent via social media by young web users. It was found that the progression of the COVID19 pandemic is accompanied by the participants' experience of negative emotions and fears of the unknown $(\mathrm{r}=.204 ; \mathrm{p}<.01)$. It is substantiated that increasing immersion of young web users in social media is a kind of strategy to escape from bad thoughts $(r=.271 ; \mathrm{p}<.01)$. Significantly, it
Accepted: April 25, 2021

Written by:

Alisar Hudimova ${ }^{14}$

https://orcid.org/0000-0001-9996-0674

Ihor Popovych ${ }^{15}$

https://orcid.org/0000-0002-1663-111X

Vita Baidyk ${ }^{16}$

https://orcid.org/0000-0003-0275-6162

Olena Buriak ${ }^{17}$

https://orcid.org/0000-0001-5960-9441

Olha Kechyk ${ }^{18}$

https://orcid.org/0000-0003-4097-1891

\section{Анотація}

Мета. Емпірично дослідити та теоретично обгрунтувати результати впливу соціальних мереж на психологічне благополуччя юних web-користувачів впродовж вимушеної самоізоляції, викликаної прогресуванням пандемії COVID-19 (n=254). Матеріали i методи: стандартизовані валідні психодіагностичні методики, авторська анкета (A. Hudimova, 2021), кореляційний та факторний аналізи. Результати. Отримано результати, які продемонстрували, що під час всесвітньої пандемії COVID-19 юні респонденти віддають перевагу пасивному використанню соціальних мереж, на відміну від спілкування. 3'ясовано зростання часу проведення у соціальних мережах webкористувачами юнацького віку. Встановлено, що прогресування пандемії COVID-19 супроводжується переживанням респондентами негативних емоцій та страхів перед невідомим $(\mathrm{r}=.204 ; \mathrm{p}<.01)$. Обгрунтовано, що збільшення занурення у соціальні мережі у юних web-користувачів $\epsilon$ своєрідною стратегією втечі від поганих думок

\footnotetext{
${ }^{14}$ PhD Candidate in Psychology of Department Practical and Clinical Psychology, Odesa I. I. Mechnikov National University, Odesa, Ukraine.

${ }^{15}$ Doctor of Psychological Sciences, Full Professor of Department of Psychology, Kherson State University, Kherson, Ukraine.

${ }^{16}$ Candidate of Psychological Sciences, Head of Department of Education Management, Luhansk Regional In-Service Teacher Training Institute, Sievierodonetsk, Ukraine.

${ }^{17}$ Candidate of Psychological Sciences, Head of Department of Natural Sciences and Methods of Teaching, Luhansk Regional InService Teacher Training Institute, Sievierodonetsk, Ukraine.

${ }^{18}$ Candidate of Pedagogical Sciences, Senior Lecturer of Department of Natural Sciences and Methods of Teaching, Luhansk Regional In-Service Teacher Training Institute, Sievierodonetsk, Ukraine.
} 
is stated that uncontrolled use of social media causes sleep disorders during isolation $(\mathrm{r}=.444$; $\mathrm{p}<.01)$. Conclusions. The study proves that young people spend almost all day online due to the obsessive pattern of social media involvement and/or procrastination, which often provokes withdrawal syndrome upon the attempt to distract from them. The lack of controlled time spending on social media during self-isolation provokes an exacerbation of anxiety, apathy, depressed mood, and a sense of isolation from social reality. The obtained results provide evidence that the causal relations of passive social media use provoke an exacerbation of feelings of alienation, disrupt the healthy rhythm of sleep, and psychological state of young webusers during the progression of the COVID-19 pandemic.

Key words: social media, stress, adaptation, mental health, psychological health.

\section{Introduction}

Social media have significantly changed the nature of communication between web users in our time. The most active users are young people aged 16 to 21 years. The social situation of development has a significant impact on selfawareness and determines the transition of the psyche and the crisis of adolescence. Intimate and personal communication with peers is an activity in which there is practical assimilation of moral norms and values. In friendly relations with the development of technology, the share of online communication is growing. However, despite the prevalence of virtual communication, the formation and maintenance of friendly relations is the predominant need of young age. The most important socio-psychological characteristics of young people are the degree of activity of their efforts to overcome life's difficulties and a sense of personal responsibility for their actions, as well as faith in a successful future (Kononenko, et. al., 2020). In adolescence, there are also such important new formations as a new level of self-awareness and change in selfconcept. These new formations are the desire to understand themselves, their capabilities, and their features. These qualities make an individual unique and inimitable.

Hypothesis. The change in the daily rhythm of life due to the progression of the COVID-19 pandemic has encouraged young web users to $(\mathrm{r}=.271 ; \mathrm{p}<.01)$. Констатовано, що наслідком неконтрольованого використання соціальних мереж під час ізоляції $\epsilon$ страждання від порушень сну ( $\mathrm{r}=.444 ; \mathrm{p}<.01)$. Висновки. Доведено, що юнаки через обсесивний патерн залучення у соціальні мережі та/або через прокрастинацію проводять майже цілий день онлайн, що нерідко провокує синдром відміни при намаганнях відволіктися. Відсутність контрольованого проведення часу $\mathrm{y}$ соцмережах під час самоізоляції провокує загострення тривоги, апатії, пригніченого настрою та відчуття відірваності від соціальної реальності. Обгрунтовано і узагальнено, що причинно-наслідкові зв'язки пасивного використання соціальних мереж провокують загострення почуття відчуженості, порушують здоровий ритм сну та психологічний стан юних web-користувачів під час прогресування пандемії COVID-19.

Ключові слова: соціальні мережі, стрес, адаптація, психічне здоров'я, психологічне здоров’я.

increase the time spent on social media. We assume that an enhancement in time spent on social media harms young web users' psychological well-being.

The study aims to empirically appraise and theoretically substantiate the results of the impact of social media on young web users' psychological well-being during the forced selfisolation caused by the progression of the COVID-19 pandemic.

\section{Literature review}

O. Stroyanovska et. al. (2020) in their study noted that the concept of psychological wellbeing is an integrative phenomenon that systematically affects various parameters of an individual's mental state. Psychological wellbeing leads to successful behavior and effective interpersonal interaction. Most researchers (Waterman, 1993; Deci \& Ryan, 2008; Kahneman \& Deaton, 2010) argue that psychological well-being is largely ensured not only by physical and mental well-being but also by the state of the social environment. The researchers and psychologists at the School of Positive Psychology have identified specific strengths needed to protect an individual from mental illness. In particular, G. Pânişoară (2017) and her colleagues pointed to several human 
qualities. They consolidate fortitude, futuresituated reasoning, confidence, relational abilities, confidence, hard working attitude, trust, trustworthiness, diligence, and the capacity to create thoughts. Along with the above-mentioned strengths, there are also other concepts, like life fulfillment, self-idea, good faith, and selfviability (Pânişoară, et al., 2017). F. Ma et al. (2020) conducted research and found that the components of psychological well-being are: life satisfaction and appreciation, trust, courage, resilience, independence, meaningfulness, and optimism.

S. Turkle's (2011) study showed that modern technologies and social media lead to the formation of new, unhealthy relationships between parents, children, friends, and other participants in communication. Studies of social media and psychological well-being show ambiguous, rather contradictory results. Scientists have found that social media users receive significant social support, a sense of community, and increased well-being. Social media provide wide admittance to data and conversationalist, offer extra instruments for making messages and permit to control the degree of namelessness. Compared to personal correspondence, these extra chances increment the level of opportunity and the sensation of overseeing social gatherings. Thus, social media can promote self-introduction and selfdivulgence of users that has a constructive outcome on psychological well-being (Valkenburg \& Peter, 2011; Kim \& Lee, 2011). However, most studies point to many negative factors associated with social media use for adolescents. Adverse effects include increased narcissism, superficial connections, increased tension, anxiety, and sleep disorders, especially if the platforms are used for excessive amounts of time (Wilson, 2012; Graham, 2008). Some studies point to a link between social media activity and emotional consequences: loneliness, changes in self-esteem, depression (Huang, 2017; Bayer, 2018; Orben \& Przybylski, 2019).

The positive and negative consequences of social media use can coexist. The results of the impact of social media on young users' psychological well-being may vary depending on personality traits and time spent online. Thus, some web users have a constructive outcome on the level of well-being, while others suffer from harmful effects (Frost \& Rickwood, 2017). A. Gonzales and J. Hancock (2011) refuted the position that the demonstration of one's information online due to differences in individual and social standards leads to a decrease in self-esteem.
Social media create favorable conditions for "impression management". Thus, viewing and editing information and profile on social media can predict an expansion in self-esteem. Mental self portrait and the image of others are quite simplified on social media, which is assessed by the number of likes and followers. Young web users often lose their mood and self-esteem when comparing themselves with more popular bloggers. This assessment is more related to the problems of cognitive categorization. Cognitive categorization near the screen of gadgets is not improved, i. e. web users do not spontaneously form new systems of coding of perceived personal information. Probably, the identified simplification effect can be explained by the specifics of the media image, which is the basic unit of coding information in cyberspace (Medvedskaya, et al., 2020). A. Orben (2020) found little negative correlation between the use of gadgets and the psychological well-being of young people. However, it is unclear whether there is a causal relation or an association due to additional factors.

It is important to study the relationship between spending time online and the psychological wellbeing of young people during the global coronavirus pandemic (SARS-CoV-2 virus). O. Khmiliar, et al. found that within the setting of the rapid spread of the COVID-19 pandemic, behavioral regulation of communication can be predicted with high probability, based on the available indexes of proxemics of interlocutors. To gain the approval of another person, the distance of interaction decreases (Khmiliar et al., 2020). The last pattern is very important in cyberspace. It is significant to support the psychological health of young people during COVID-19 because their psyche is actively formed. The researcher J. Gruber and his colleagues (2020) have identified three fundamental manners by which the COVID-19 pandemic influences mental health. Firstly, this pandemic is long-term, disrupts daily life, and makes genuine vulnerability about the present and the future. Secondly, social interaction is disrupted and minimized, which exacerbates the feeling of loneliness. Thirdly, the current pandemic deprives young people of stabilizing social interaction with their loved ones because of the significant risk of infection. Not the least role is played by forced self-isolation, which leads to exacerbation of loneliness and progression of anxiety and depression (Danace, et al., 2020; Skliar et al., 2021).

The aim of Y. Yang et al. (2020) study was to find-out in-what-manner social media impede 
people's mental health while quarantine. The results show that extensive social media use during a pandemic leads to a state of distress. Similar results were obtained by the researchers A. Ahmad and H. Murad (2020). Their research shows that social media play a significant role in influencing the public during the COVID-19 pandemic. The researchers point out that there is a significant positive statistical correlation between social media and the spread of panic about COVID-19, especially among the younger generation (18-35 years). Web users prefer information from social media. Regularly they cannot recognize which data on social media is genuine and which is not. Such behavior causes indeed more fright and rumors almost the genuine nature of the epidemic. The researcher K. Tugberk (2020) came to the opposite conclusion, noting that web users take after official sources which anticipate the expanse of fake news. The author argues that users' selfawareness reduces panic because they do not accept fake news, indeed in the event that they are "struck" by them. Users also believe that social media posts create an accelerated panic associated with COVID-19. The results of his study convey that the social media use during COVID-19 is non-identical from the usual online pastime. Usually, before the COVID-19 pandemic, most web users wanted to show the perfect picture of their lives to others, that in turn could be alarming to the latter. Individuals were in self-isolation and had comparative conditions amid the pandemic. As a result, comparable designs of behavior were taken after without causing concern to other users (Bingimlas, 2021; Tugberk, 2020).

The study of the pandemic's impact on social media use among youth is extremely relevant. On the one hand, social media are one of the main and safe means of communication with friends and family, which can be a source of social support (Mastrotheodoros, 2020). Under other conditions, pre-pandemic research has linked young people to excessive social media use and low levels of psychological well-being. The most common manifestations of decreased psychological well-being are signs of depression and risky behavior. The study by A. Eden et al. (2020) shows how stress and anxiety due to social distancing are related to different patterns of social media use among university students throughout global pandemic. It establishes how social media use is related to the mental health and psychological well-being of young web users. The results indicate that the participants had an expanded propensity to use social media as a coping strategy. This type of behavior is associated with a positive effect that improves psychological well-being. These results emphasize the feasibility of social media use as a mental asset in times of emergency. Stress and anxiety have been linked to both adaptive and non-adaptive forms of social media use. Stress has been linked to escapism on social media. Escapism suggests that web users have tried to emotionally avoid their current level of stress through hedonistically pleasurable social media choices that are unrelated to COVID-19 experiences (Eden et al., 2020).

The study results of Y. Yang et al. (2020) demonstrated that the manner of using social media is important. In specific, individuals who were more likely to share positive data about COVID-19 on social media tended to have higher levels of life fulfillment as well as lower levels of depression and anxiety. At the same time, individuals who were slanted to take part in discourses around COVID-19 on social media had higher anxiety and lower levels of life fulfillment. Hence, diverse ways of social media use can have diverse impacts on psychological well-being. Other than, the investigation found that activities on social media can have a coordinate affect on mental health.

The researchers V. Boursier et al. (2020) found that increasing feelings of loneliness and isolation involved high levels of anxiety and social media overuse. Simplified and long-term access to social media has become a familiar reaction of a person to remain in touch throughout the quarantine. However, this decision may reflect the fear of the unknown through a pandemic. Excessive social media use, according to the authors, is a strategy to overcome feelings of loneliness. Per contra, in some circumstances, this may be an inadequate technique that heightens the anxiety of single people in the specific circumstances of a pandemic.

Thus, the study of the impact of social media on the psychological well-being of youth during the progression of the COVID-19 pandemic is relevant and extremely important.

\section{Materials and methods}

Methodological foundations of the empirical study of the impact of social media on young web users' psychological well-being are based on the psychology of users' interaction in cyberspace. To a greater extent, research on interaction in 
social media is conducted by Western European scientists. At the same time, the obtained empirical facts are quite contradictory (Verduyn et al., 2017; Frison \& Eggermont, 2015; Appel et al., 2015). Of course, the leading research is in the medical field, at the same time the study of medical psychology deserves attention. The phenomenon of social media disorder has been established and substantiated, which combines the following criteria: neglect of personal life, mental anxiety, escapism, mood swings, tolerance, concealment of addictive behavior (Pryzbylski et al., 2013; Young et al., 2017; Eijnden et al., 2016).

The logic of constructing an "empirical picture" was used in the development of the methodology for studying the impact of social media on young web users' psychological well-being during the progression of the COVID-19 pandemic. The latter is reflected in the studies of the selfregulatory capacity of an individual (Blynova et al., 2020c; Halian et al., 2020b; Popovych et al., 2020), personality adaptation (Arbeláez-Campillo et al., 2018; Blynova et al., 2020a; 2020d; Halian et al., 2020a), educational activities of respondents of different ages (Blynova et al., 2020b; Halian et al., 2020c; Shevchenko et al., 2020 Tsiuniak et al., 2020). The scientific studies listed by us are directly associated with the research of the impact of social media on young web users' psychological well-being.

Participants. The study involved 254 people aged 16-21 years. The study was conducted in the form of questionnaires on the Google Form platform during the progression of the COVID19 pandemic. Information about the research is posted on the websites of colleges and universities in Odesa (Ukraine), as well as disseminated in social media applications, due to the age restrictions of the study category. Participation was voluntary, incognito, and no biographical data was collected. The sample size is determined by the number of participants who correctly and completely filled out the questionnaires.

Organization of Research. The research procedure was to fill in the questionnaire. Each questionnaire was accompanied by instructions. The instructions list aspects of the study, such as confidentiality, purpose and time. The author's questionnaire was used to collect data on the socio-demographic characteristics of young web users (Hudimova, 2021). The WarwickEdinburgh psychological well-being scale was used to study the psychological and individual spheres ( $\alpha$-Cronbach's coefficient was $\alpha=.85$ ) (Tennant et al., 2007); The loneliness experience questionnaire ( $\alpha$-Cronbach's ratio was $\alpha=.77$ ) (Korchagina, 2008) and the Social Media Disorder Scale ( $\alpha$-Cronbach's ratio was $\alpha=.82$ ) (Eijnden et al., 2016). The questionnaires consisted of multiple options, rating scales (Likert scale) and closed-ended questions. In addition, to assess the condition of the respondents due to the forced self-isolation during the progression of the COVID-19 pandemic, the following questions were added: "Increased online communication", "Behavior change", "Nature of thoughts about isolation", "Frequency of social media distraction" and "Sleep changes".

Procedures. The empirical study was conducted in the form of a confirmatory experiment. The obtained results were interpreted separately for each diagnostic method. The next step in the study was to establish the causal relations between the social media impact on the young web users' psychological well-being. The degree of the interrelation of the studied phenomena consisted in the analysis and confirmation of the reliability of the obtained results by mathematical statistics methods. The study was performed by the ethical standards of the WMA Declaration of Helsinki (2013).

Statistical Analysis. Mathematical analysis of the obtained empirical data was performed using statistical software packages IBM SPSS Statistics v. 23.0.0. The research uses the Pearson correlation coefficient (r) and factor analysis by ANOVA method.

\section{Results}

As a result of the study, it was possible to record the characteristics of the behavior of young web users during the forced self-isolation (Tabl. 1). 
Table 1.

Matrix of Correlations of the Studied Indexes of the Impact of Social Media on Young Web Users' Psychological Well-being During the Progression of the COVID-19 Pandemic.

\begin{tabular}{ll}
\hline Index & Pearson correlation coefficient (r) \\
\hline Experience in Social Media Use & $\mathrm{r}=.294 ; \mathrm{p}=.0001$ \\
Time Spent on Social Media per Day & $\mathrm{r}=-.250 ; \mathrm{p}=.0001$ \\
Sleep Changes & $\mathrm{r}=-.178 ; \mathrm{p}=.005$ \\
Social Media Disorder Scale & $\mathrm{r}=-.137 ; \mathrm{p}=.03$ \\
Withdrawal & $\mathrm{r}=-.196 ; \mathrm{p}=.002$ \\
\hline
\end{tabular}

Spending an excessive amount of time on social media leads to a decrease in the level of psychological well-being. To test this complex phenomenon, it was decided to conduct factor analysis by ANOVA (Tabl. 2).

Table 2.

Inverse Components' Matrix of Analysis of Young Web Users' Psychological Disorders and Excessive Social Media Use Indicators.

\begin{tabular}{lll}
\hline Index & \multicolumn{2}{c}{ Component } \\
& $\mathbf{1}$ & $\mathbf{2}$ \\
\hline Social Media Disorder Scale & .789 & .454 \\
Preoccupation & .731 & \\
Tolerance & .722 & \\
Time Spent on Social Media per Day & .631 & \\
Number of Accounts & .553 & \\
Escape from Bad Thoughts in Social Media & .549 & \\
Avoiding Behavior & .504 & \\
Feelings in Connection with Quarantine & & -.668 \\
Depth of Loneliness Experience & & .535 \\
Behavior Changes due to Quarantine & & -.520 \\
The Warwick-Edinburgh Mental Wellbeing Scale & & -.514 \\
Sleep Changes & & .512 \\
Conflict & & .508 \\
\hline
\end{tabular}

Notes: Method of fact finding: principal component analysis. Rotation method: Varimax with Kaiser normalization. The rotation converged in three iterations.

Healthy sleep is extremely important for maintaining the psychological well-being of young people. However, due to the inability to organize time spent on social media properly for their psychological state, young people neglect sleep, which is illustrated in Fig. 1. 


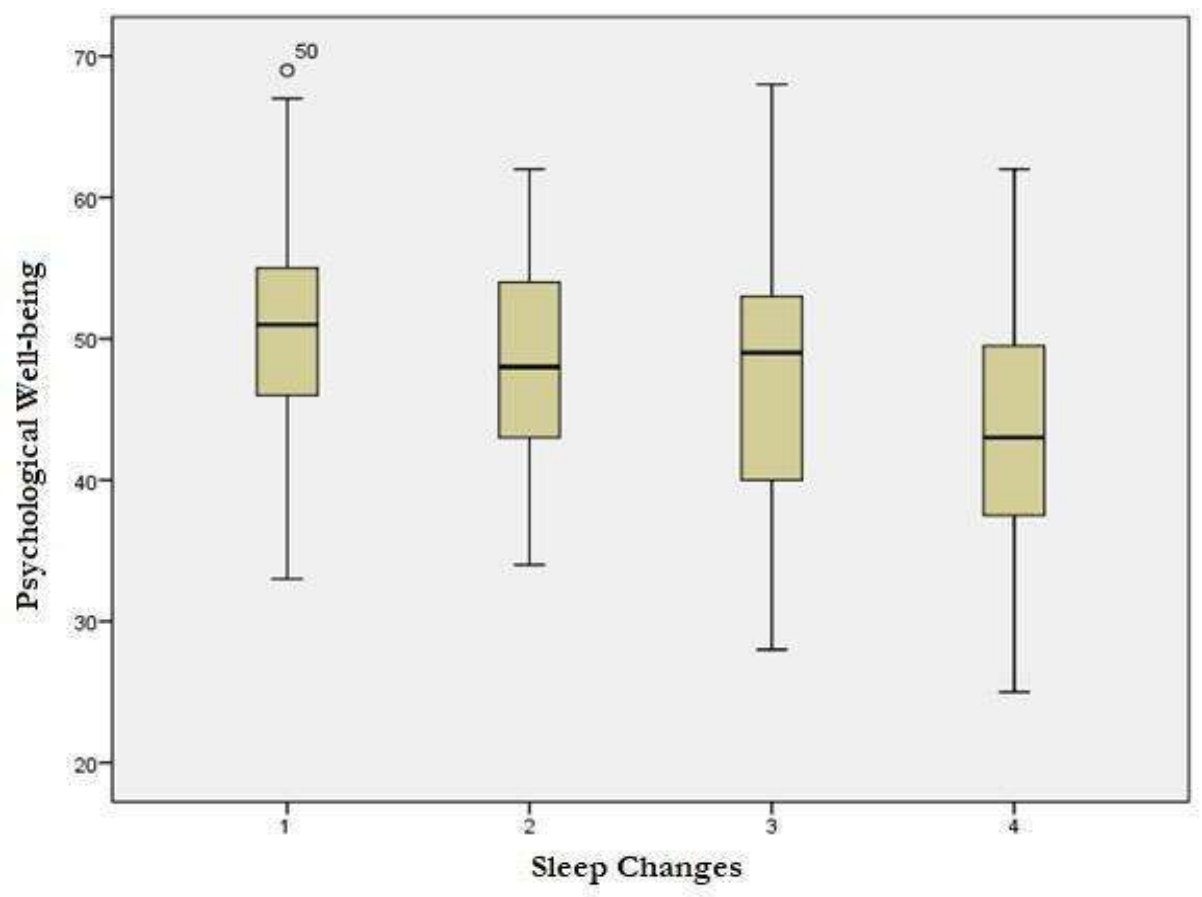

Figure 1. Diagram of the Extent of Young Web Users'

Sleep Changes and Psychological Well-being.

The results of the Warwick-Edinburgh Mental Wellbeing Scale $(\mathrm{M}=48.66 ; \pm \mathrm{SD}=8.35)$ indicate a below-average level of psychological well-being, which is one of the consequences of sleep disturbance $(r=-.280 ; p=.001)$ due to young web users' excessive social media involvement.

\section{Discussion}

The study of the infuence's specifics of social media on the psychological state of the younger generation during the COVID-19 pandemic is novel. However, there are modern tangential studies with quite interesting results. The scientist W. Ellis et al. (2020) found that young users spend more and more time on social media and chat with friends during a pandemic. Researchers have found that depression increases at the same time. Central to this work is the positive significant correlation between stress and depression due to the current situation. Thus, the more young people report the stress associated with COVID-19, the more socially dangerous the current situation is (Ellis et al., 2020). Similar conclusions have been reached by other scientists. Accentuation is put on the truth that the predominance of mental wellbeing issues is related to the recurrence of social media use amid COVID-19 (Park et al., 2020; Tillman et al., 2020).
The results of the studies by $\mathrm{K}$. Tomaszek and A. Muchacka-Cymerman (2020) suggest that psychological disorders are associated with existential crises. These emergencies are demonstrated by the tall existential anxiety feeling amid the COVID-19 pandemic. This condition leads to a diminution in life fulfillment and post-traumatic development. An emergency is an opportunity to develop, acknowledge misfortunes and distinguish shortcomings within the human mind, as well as distinguish a few capacities to discover mental and psychoemotional adjust. The capacity to overcome challenges, to adjust, to recoup in traumatic circumstances, to discover meaning in presence can be actuated in individuals through having this unused encounter of the COVID-19 pandemic (Luca et al., 2020).

Returning to the hypothesis posed at the beginning of this study, the following was established regarding the impact of social media on the Ukrainian youth's psychological wellbeing during the pandemic. The experience of using social media is related to the activity's proportion of users in social media. With age, that is, the earlier young people become users, the less time they spend on social media. This regularity is caused by the fact that at the age of 18-21 years, users have several accounts in different applications to be in trend and be a part of a larger community. Quite often this happens to be approved by peers. There is a sufficient amount of studies that draw attention to this feature of the young age period. In particular, the 
research of A. Shevchenko (2019) found that in youth there are transformations in the valuesemantic sphere of personality. It is important that when they become mature, young people do not betray their values under the pressure of social expectations of 'significant others' and society.

Young users aged 18-21 years carefully design their profiles, blog regularly, and communicate with others to maintain activity on the page. The online behavior of the older group is not accompanied by bigotry, unlike the younger group aged 16-17 years. However, the lack of time management during the pandemic in social media use leads to sleep disorders and triggers for the development of social media disorder, which manifests in the form of irritability and anxiety. The proof of the obtained data is paired correlations in the range from $r=.320$ to $r=.592$.

Analysis of the data led to the conclusion that young web users have problems with falling asleep, therefore they use gadgets at bedtime to prepare for it. Such behavioral pattern leads to the phenomenon of a 'rabbit hole', that in turn increases the time spent on social media until the morning.

Spending time on social media leads to the emergence and progression of emotional and cognitive arousal, which in turn leads to sleep disorders $(r=.444 ; p=.01)$. Excessive social media involvement during the day often leads to delays in homework or other household chores. Such behavior ultimately leads to a violation of the regime in general. In particular, many studies demonstrate that checking social media at bedtime leads to changes in circadian rhythms due to the emission of blue shortwave light gadgets (Chang et al., 2015).

The study shows that due to self-isolation, young people experience significant psychological stress due to fear of the unknown and changes in the usual rhythm of life $(r=.204 ; p=.01)$. By focusing on the virtual world, through which young people can support the basic mechanisms of socialization, they create an acceptable atmosphere to displace bad thoughts. Social media are a simulation of real life, the only difference is the distance between users. Owing to social media, young people do not lose their socialization skills, actively communicating with other users. With passive social media use, on the contrary, young web users feel the illusion of involvement in the community without directly interacting with others. The latest pattern of social media use often leads to depression, anxiety, and detachment over time.

Young people use social media as a shelter, creating a safe news feed, they feel safe, not immersed in negative experiences, and reduce the severity of the current state of loneliness $(\mathrm{r}=.194 ; \mathrm{p}=.01)$.

According to the survey, to combat boredom and to distract from homework, young people watch movies and TV series, spend time on YouTube and TikTok. The situation with forced selfisolation is perceived by young people as an unplanned vacation. At the same time, they have difficulties due to the inability to leave the house and meet with friends. However, the share of communication on social media has not increased but even decreased. In the interview, it was found that communication during distance learning is quite exhausting, so young people prefer to spend time on social media passively. As described above, passive social media use creates the illusion of involvement in a large circle at the same time but exacerbates the feeling of loneliness. Thus, young people become the cause of their loneliness due to the ambivalence of the urges of communication - solitude.

\section{The results of the study revealed that young}

web users with a level of psychological wellbeing in the range from 47 to 69 points do not have sleep problems. With the right routine and owing to the efforts of their will, young people can stop spending time on social media and prepare for sleep.

Taken together, these findings stated that due to the lack of a normalized daily routine for the period of self-isolation, young people increase their activity in social media, which has negative consequences for psychological well-being and health in general.

\section{Conclusions}

Spending a lot of time on social media during a pandemic exacerbates the feeling of separation from others, which has negative consequences for psychological well-being $(r=.307 ; p=.01)$. The study provides additional information that the unsatisfactory level of psychological wellbeing is associated with an exacerbation of the imbalance in the mechanisms of identification and alienation. The latter is accompanied by a spoiled/depressed mood, anxiety, even greater 
immersion in social media to escape from problems and unpleasant thoughts.

Young people experience a state of tension and fear due to the unknown during the pandemic that leads to an increase in spending time on social media to get rid of negative obsessions $(r=-.219$; $\mathrm{p}=.01)$.

Social media have not only negative effects on young people during a pandemic. The positive role is the ability to expand the circle of communication with users from around the world, to be at the center of events and current trends, to create interesting creative content, and to participate in interesting discussions.

The reasons for the formation of social media disorder are the lack of self-control and time management among young people when using social media $(r=.340 ; p=.01)$.

The study provides additional information on the specifics of the impact of social media on young web users' psychological well-being during the quarantine.

\section{References}

Ahmad, A, \& Murad, H. (2020). The Impact of Social Media on Panic During the COVID-19 Pandemic in Iraqi Kurdistan: Online Questionnaire Study. J Med Internet Res, Vol. 22(5), e19556. https://doi.org/10.2196/19556

Amin, S. (2020). Why Ignore the Dark Side of Social Media? A Role of Social Media in Spreading Corona-Phobia and Psychological Well-Being. International Journal of Mental Health Promotion, 22(1), 29-38. https://doi.org/10.32604/IJMHP.2020.011115

Appel, H., Crusius, J., \& Gerlach, A. L. (2015). Social comparison, envy, and depression on Facebook: A study looking at the effects of high comparison standards on depressed individuals. Journal of Social and Clinical Psychology, 34(4). 277-289.

https://doi.org/10.1521/jscp.2015.34.4.277

Arbeláez-Campillo, D., Rojas-Bahamón, M. J., \& Arbeláez-Encarnación, T. (2018). Apuntes para el debate de las categorías ciudadanía universal, derechos humanos y globalización. Notes for the debate of the categories universal citizenship, human rights and globalization. Cuestiones Políticas, 34(61), 139-160.

Bayer, J., Ellison, N., Schoenebeck, S., Brady, E., \& Falk, E. B. (2018). Facebook in context(s): measuring emotional responses across time and space. New Media Soc, 20(3),
1047-1067.

https://doi.org/10.1177/1461444816681522

Bingimlas, K. (2021). Investigating the application of emergency remote teaching during the COVID-19 pandemic in higher education. Amazonia Investiga, 10(37), 56-67. https://doi.org/10.34069/AI/2021.37.01.5

Blynova, O., Chervinska, I., Kazibekova, V. et al. (2020a). Social and Psychological Manifestations of Professional Identity Crisis of Labor Migrants. Revista Inclusiones, 7(3), 93105.

http://www.revistainclusiones.org/index.php/inc lu/article/view/1318

Blynova, O., Lappo, V., Kalenchuk, V. et al. (2020b). Corporate Culture of a Higher Education Institution as a Factor in Forming Students' Professional Identity. Revista Inclusiones, 7(Especial), 481-496. http://www.revistainclusiones.org/index.php/inc lu/article/view/1305

Blynova, O., Moiseienko, V., Los, O. et al. (2020c). Assertiveness as a Factor of Students' Choice of Behavior Strategies in Social Interaction. Revista Inclusiones, 7(4), 259-272. http://www.revistainclusiones.org/index.php/inc lu/article/view/1551

Blynova, O., Popovych, I., Semenova, N. et al. (2020d). Personality Factors of Choosing Adaptation Strategies in a Different Cultural Environment by Labor Migrants from Ukraine. Revista Amazonia Investiga, 9(32), 45-54. Retrieved from http://dx.doi.org/10.34069/AI/2020.32.08.5

Boursier, V., Gioia, F., Musetti, A., \& Schimmenti, A. (2020). Facing Loneliness and Anxiety During the COVID-19 Isolation: The Role of Excessive Social Media Use in a Sample of Italian Adults. Frontiers in Psychiatry, 11, 1380 .

https://www.frontiersin.org/article/10.3389/fpsy t.2020.586222

Chang, A. M., Aeschbach, D., Duffy, J. F., \& Czeisler, C. A. (2015). Evening use of lightemitting eReaders negatively affects sleep, circadian timing, and next-morning alertness. Proc Natl Acad Sci U S A, 112(4), 1232-1237.

Danace, A., Smith, P., Chitsabesan, P., \& Dubicka, B. (2020). Child and adolescent mental health amidst emergencies and disasters. The British Journal of Psychiatry, 216(30), 159-162. https://doi.org/10.1192/bjp.2019.244

Deci, E. L., \& Ryan, R. M. (2008). Selfdetermination theory: a macrotheory of human motivation, development, and health. Canadian Psychology-Psychologie Canadienne, 49(3), 194-200.

Eden, A. L., Johnson, B. K., Reinecke, L., \& Grady, S. M. (2020). Media for Coping During 
COVID-19 Social Distancing: Stress, Anxiety, and Psychological Well-Being. Frontiersin Psychology, 11, 3388. https://doi.org/10.3389/fpsyg.2020.577639 Eijnden, R., Lemmens, J., \& Valkenburg, P. (2016). The Social Media Disorder Scale: Validity and psychometric properties. Computers in Human Behavior, 61, 478-487. https://doi.org/10.1016/j.chb.2016.03.038

Ellis, W. E., Dumas, T. M., \& Forbes, L. M. (2020). Physically isolated but socially connected: Psychological adjustment and stress among adolescents during the initial COVID-19 18 crisis. Canadian Journal of Behavioural Science / Revue Canadienne Des Sciences Du Comportement, 52(3), 177-187. https://doi.org/10.1037/cbs0000215

Frison, E., \& Eggermont, S. (2015). Exploring the Relationships Between Different Types of Facebook Use, Perceived Online Social Support, and Adolescents' Depressed Mood. Social Science Computer Review, 34(2), 153-171. https://doi.org/10.1177/0894439314567449

Frost, R. L., \& Rickwood, D. J. (2017). A systematic review of the mental health outcomes associated with facebook use. Comput Hum Behav, 76, 576-600. https://doi.org/10.1016/J.CHB.2017.08.001 Gonzales, A., \& Hancock, J. T. (2011). Mirror, mirror on my Facebook wall: Effects of exposure to Facebook on self-esteem. Cyberpsychology, Behavior, and Social Networking, 14,79-83. https://doi.org/10.1089/cyber.2009.0411

Graham, C. (2008). Happiness and Health: Lessons and Questions - For Public Policy. Health Affairs, 27, 1, 72-87.

Gruber, J., Prinstein, M. J., Clark, L. A., Rottenberg, J., Abramowitz, J. S., Albano, A. M., Aldao, A., Borelli, J. L., Chung, T., Davila, J., Forbes, E. E., Gee, D. G., Hall, G. C. N., Hallion, L. S., Hinshaw, S. P., Hofmann, S. G., Hollon, S. D., Joormann, J., Kazdin, A. E., ... Weinstock, L. M. (2020). Mental health and clinical psychological science in the time of COVID-19: Challenges, opportunities, and a call to action. American

https://doi.org/10.1037/amp0000707

Psychologist.

Halian, A., Halian, I., Burlakova, I., Shevchenko, R., Lappo, V., Zhigarenko, I., \& Popovych, I. (2020a). Emotional Intelligence in the Structure of Adaptation Process of Future Healthcare Professionals". Revista Inclusiones, 7(3), 447-460. http://www.revistainclusiones.org/index.php/inc lu/article/view/1347

Halian, I., Machynska, N., Lozynska, S. et al. (2020b). Tolerance of uncertainty as a component of the process of life-creation of future educators. Revista Inclusiones, 7 (Especial), 512-528. http://www.revistainclusiones.org/index.php/inc lu/article/view/1307

Halian, I. M., Halian, O. I., Gusak, L. Ye. et al. (2020c). Communicative Competence in Training Future Language and Literature Teachers. Revista Amazonia Investiga, 9(29), 530-541. Retrieved from https://amazoniainvestiga.info/index.php/amazo nia/article/view/1417

Huang, C. (2017). Time spent on social network sites and psychological well-being: A metaanalysis. Cyberpsychology, Behavior, and Social Networking, 20, 346-354. https://doi.org/10.1089/cyber.2016.0758

Hudimova, A. (2021). Adolescents' Involvement in Social Media: Before and During Covid-19 Pandemic. International Journal of Innovative Technologies in Social Science, 1(29). https://doi.org/10.31435/rsglobal_ijitss/3003202 $1 / 7370$

Kahneman, D., \& Deaton, A. (2010). High income improves evaluation of life but not emotional well-being. Proceedings of the National Academy of Sciences, 107(38), 16489-16493.

https://doi.org/10.1073/pnas.1011492107

Khmiliar, O., Popovych, I., Hrys, A. et al. (2020). Spatial Regulation of Personality Behavior in the Conditions of Progression of the COVID-19 Pandemic. Revista Inclusiones, 7(Especial), 289306.

http://www.revistainclusiones.org/index.php/inc lu/article/view/1760

Kim, J., \& Lee, J. E. R. (2011). The Facebook paths to happiness: Effects of the number of Facebook friends and self-presentation on subjective well-being. CyberPsychology, behavior, and social networking, 14(6), 359-364. Kononenko, O., Kononenko, A., Stynska, V. et al. (2020). Research of the factor structure of the model of world view settings at a young age. Revista Inclusiones, 7(3), 98-116. http://www.revistainclusiones.org/index.php/inc lu/article/view/1618

Korchagina, S. G. (2008). The psychology of loneliness: a textbook. Moscow: Moscow Psychological and Social Institute.

Liu, D., \& Campbell, W. K. (2017). The Big Five personality traits, Big Two metatraits and social media: A metaanalysis. Journal of Research in Personality, 70 , 229-240. https://doi.org/10.1016/j.jrp.2017.08.004 Luca, L., Baroiu, L., Ciubara, A. B., Anghel, R., Bulgaru-Iliescu, A. I., Anghel, L., \& Ciubara, A. (2020). Covid-19 and the Spanish Flu. From Suffering to Resilience. BRAIN. Broad Research 
in Artificial Intelligence and Neuroscience, 11(3Sup1), 01-07.

https://doi.org/10.18662/brain/11.3Sup1/116

Ma, F., Shevchenko, R. P., \& Karhina, N. V. (2020). Student you three presentation of psychological well-being: results of content analysis of works. Insight: the psychological dimensions of society, 3, 44-55. https://doi.org/10.32999/2663-970X/2020-3-3

Mastrotheodoros, S. (2020). The effects of COVID-19 on young people's mental health and psychological well-being. Youth Partnership by the European Union - Council of Europe.

Medvedskaya, E. I., Onufriieva, L. A. \& Tavrovetska, N. I. (2020). The semantic space of the personality of adult active web-users. Insight: the psychological dimensions of society, 4, 4256. https://doi.org/10.32999/2663-970X/2020-43

Orben, A. (2020). Teenagers, screens and social media: a narrative review of reviews and key studies. Social Psychiatry and Psychiatric Epidemiology. https://doi.org/10.1007/s00127019-01825-4

Orben, A., \& Przybylski, A. K. (2019). The association between adolescent well-being and digital technology use. Nature Human Behaviour, 3 , 173-182. https://doi.org/10.1038/s41562-018- 0506-1

Pânişoară, G., Pânişoară, I. O., Sandu, C., \& Chirca, R. (2017). The Status of Positive Psychology Strengths within the Romanian School in the Digital Society. BRAIN. Broad Research in Artificial Intelligence and Neuroscience, $\quad 7(4), \quad 5-22$. https://lumenpublishing.com/journals/index.php /brain/article/view/1990

Park, C. L., Russell, B. S., Fendrich, M., Finkelstein-Fox, L., Hutchison, M., \& Becker, J. (2020). Americans' COVID-19 Stress, Coping, and Adherence to CDC Guidelines. Journal of General Internal Medicine, 1.

Popovych, I., Zhigarenko, I., Losiyevska, O. et al. (2020). Research of Achievement Motivation's Impaction the Career Orientations of Future Managers of Organization. Revista Inclusiones, 7(Especial), 247-263. http://www.revistainclusiones.org/index.php/inc lu/article/view/1231

Pryzbylski, A., Murayama, K., DeHaan, C. \& Gladwell, V. (2013). Motivational, emotional and behavioural correlates of fear of missing out. Computers in Human Behaviour, 29(4), 18411848. https://doi.org/10.1016/j.chb.2013.02.014 Shevchenko, A. V. (2019). Research on the correlation between social desirability and value orientations in adolescence. Insight: the psychological dimensions of society, 1, 90-94. https://doi.org/10.32999/2663-970X/2019-1-14
Shevchenko, R., Popovych, I., Spytska, L. et al. (2020). Comparative analysis of emotional personality traits of the students of maritime science majors caused by long-term staying at sea. Revista Inclusiones, 7(Especial), 538-554. http://www.revistainclusiones.org/index.php/inc lu/article/view/1309

Stroyanovska, O., Dolynska, L., Shevchenko, N., Andriiashyna, N., Melnyk, I., \& Tsybuliak, N. (2020). The Influence of the Professional Orientation of Students of Different Gender on Their Ideas of Happiness. BRAIN. Broad Research in Artificial Intelligence and Neuroscience, $\quad 11(4), \quad 51-71$. https://doi.org/10.18662/brain/11.4/141

Tennant, R., Hiller, L., Fishwick, R., Platt, S., Joseph, S., Weich, S., Parkinson, J., Secker, J., \& Stewart-Brown, S. (2007). The WarwickEdinburgh Mental Well-being Scale (WEMWBS): Development and UK validation. Health and Quality of Life Outcomes, 5, Article 63. https://doi.org/10.1186/1477-7525-5-63

Skliar, N., Begma, V., \& Vrublevska, O. (2021). New challenges for the defense industrial enterprises of Ukraine in the conditions of the global pandemic. Amazonia Investiga, 10(37), 45-55. https://doi.org/10.34069/AI/2021.37.01.4 Tillman, G., March, E., Lavender, A. P., \& Mesagno, C. (2020). Disordered Social Media Use and Fear of COVID-19 and the Association with Stress and Depression. PsyArXiv. https://doi.org/10.31234/osf.io/dbg62

Tomaszek, K., \& Muchacka-Cymerman, A. (2020). Thinking about My Existence during COVID-19, I Feel Anxiety and Awe - The Mediating Role of Existential Anxiety and Life Satisfaction on the Relationship between PTSD Symptoms and Post-Traumatic Growth. Int. J. Environ. Res. Public Health, 17, 7062. https://doi.org/10.3390/ijerph17197062

Tsiuniak, O., Pyslar, A., Lialiuk, G. et al. (2020). Research of interdependence of variables and factor structure of masters' readiness for innovative pedagogical activity. Revista Inclusiones, 7(3), 427-452. http://www.revistainclusiones.org/index.php/inc lu/article/view/1645

Tugberk, K. (2020). The changes in the effects of social media use of Cypriots due to COVID-19 pandemic. Technology in Society, 63, 101380. https://doi.org/10.1016/j.techsoc.2020.101380

Turkle, S. (2011). Alone Together: Why we expect more from technology and less from each other. New York: Basic Books.

Valkenburg, P. M., \& Peter, J. (2011). Online communication among adolescents: An integrated model of its attraction, opportunities, and risks. Journal of Adolescent Health, 48, 
121-127.

https://doi.org/10.1016/j.jadohealth.2010.08.020 Verduyn, P., Ybarra, O., Résibois, M., Jonides, J., \& Kross, E. (2017). Do Social Network Sites Enhance or Undermine Subjective Well-Being? A Critical Review. Social Issues and Policy Review, 11(1), 274-302. https://doi.org/10.1111/sipr.12033

Waterman, A. S. (1993). Two conceptions of happiness: Contrasts of personal expressiveness (eudaimonia) and hedonic enjoyment. Journal of Personality and Social Psychology, 64(4), 678691.

Wilson, R. E., Gosling, S. D., \& Graham, L. T. (2012). A review of Facebook research in the social sciences. Persp. Psychol. Sci, 7(3), 203-220.
World Medical Association Declaration of Helsinki. (2013). Ethical principles for medical research involving human subjects, 310(20), 2191-4.

https://doi.org/10.1001/jama.2013.281053

Yang, Y., Liu, K., Li, S., \& Shu, M. (2020). Social Media Activities, Emotion Regulation Strategies, and Their Interactions on People's Mental Health in COVID-19 Pandemic. International Journal of Environmental Research and Public Health, 17(23), 8931. http://dx.doi.org/10.3390/ijerph17238931 Young, N. L., Kuss, D. J., Griffiths, M. D., \& Howard, C. J. (2017). Passive Facebook use, Facebook addiction, and associations with escapism: An experimental vignette study. Computers in Human Behavior, 71, 24-31. 